\begin{tabular}{|c|c|}
\hline $\begin{array}{l}\text { 2. To: (Receiving Organization) } \\
\text { DISTRIBUTION }\end{array}$ & $\begin{array}{l}\text { 3. From: coriginating orga } \\
\text { CHARACTERIZATION EQ }\end{array}$ \\
\hline $\begin{array}{l}\text { 5. Proj./Prog./Dept./Div.: } \\
\text { TECHNOLOGY DEV./7R300/TWRS }\end{array}$ & $\begin{array}{l}\text { 6. Cog. Engr.: } \\
\text { P. M. FRANCIS }\end{array}$ \\
\hline
\end{tabular}

2. To: (Receiving Organization)

DISTRIBUTION

4. Related EDT No.:

5. Proj./Prog./Dept./Div.:

6. Cog. Engr.:

605715

QPMENT

order No.:

7. Purchase Order $\mathrm{N} / \mathrm{A}$

9. Equip./Component No.:

$\mathrm{N} / \mathrm{A}$

11. Receiver Remarks:

10. System/Bldg./Facility:

$\mathrm{N} / \mathrm{A}$

12. Major Assm. Dwg. No.:

$N / A$

13. Permit/Permit Applic. No.: $N / A$

14. Required Response Date:

$\mathrm{N} / \mathrm{A}$

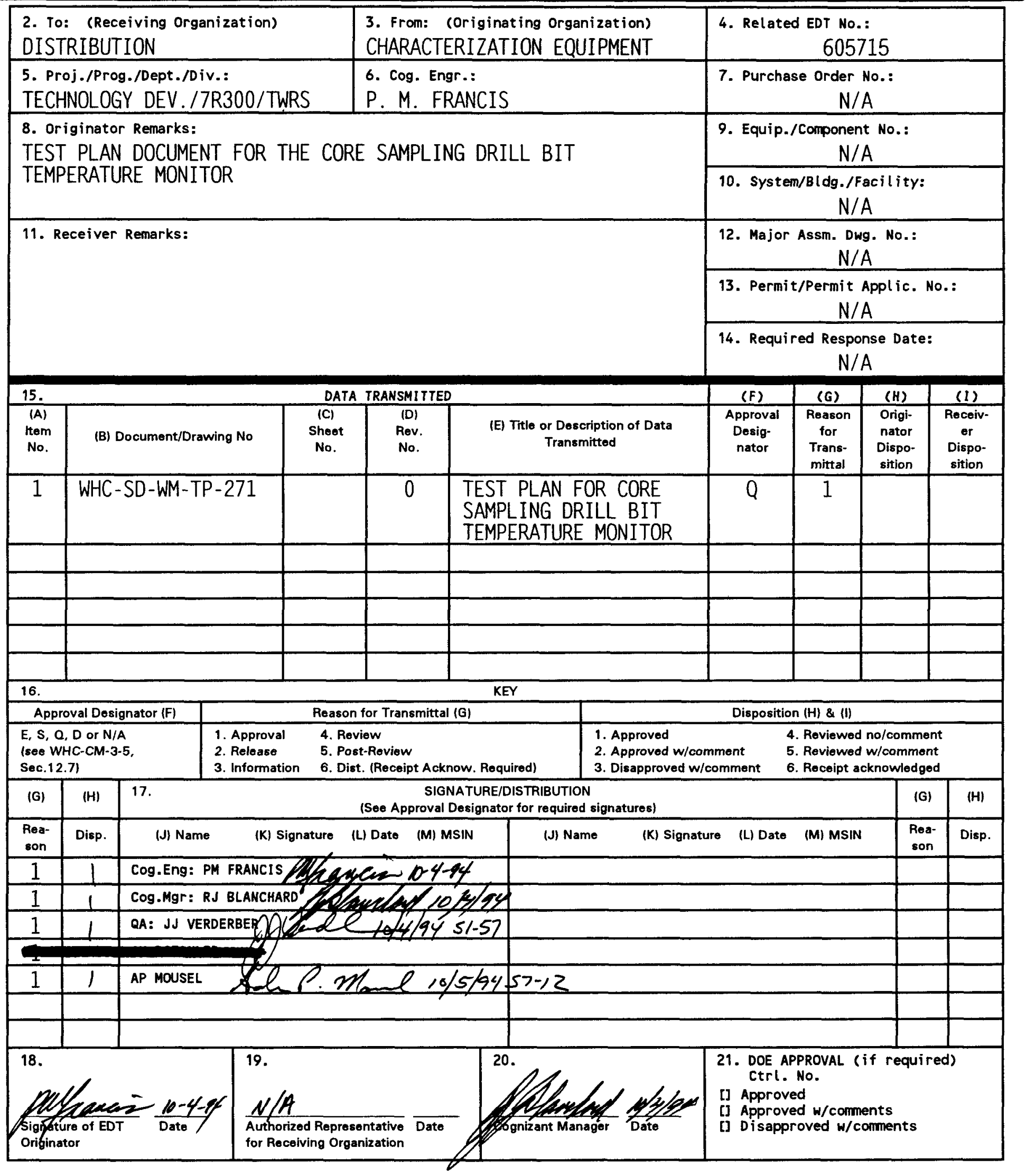

BD-7400-172-2 (04/94) GEF097

BD-7400-172-2 (04/94) GEFO97

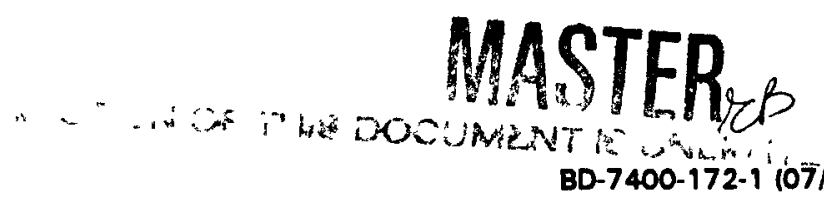




\section{RELEASE AUTHORIZATION}

Document Number: WHC-SD-WM-TP-271, REV 0

Document Title: TEST PLAN FOR CORE SAMPLING DRILL BIT TEMPERATURE MONITOR

Release Date: October 5, 1994

This document was reviewed following the procedures described in WHC-CM-3-4 and is:

APPROVED FOR PUBLIC RELEASE

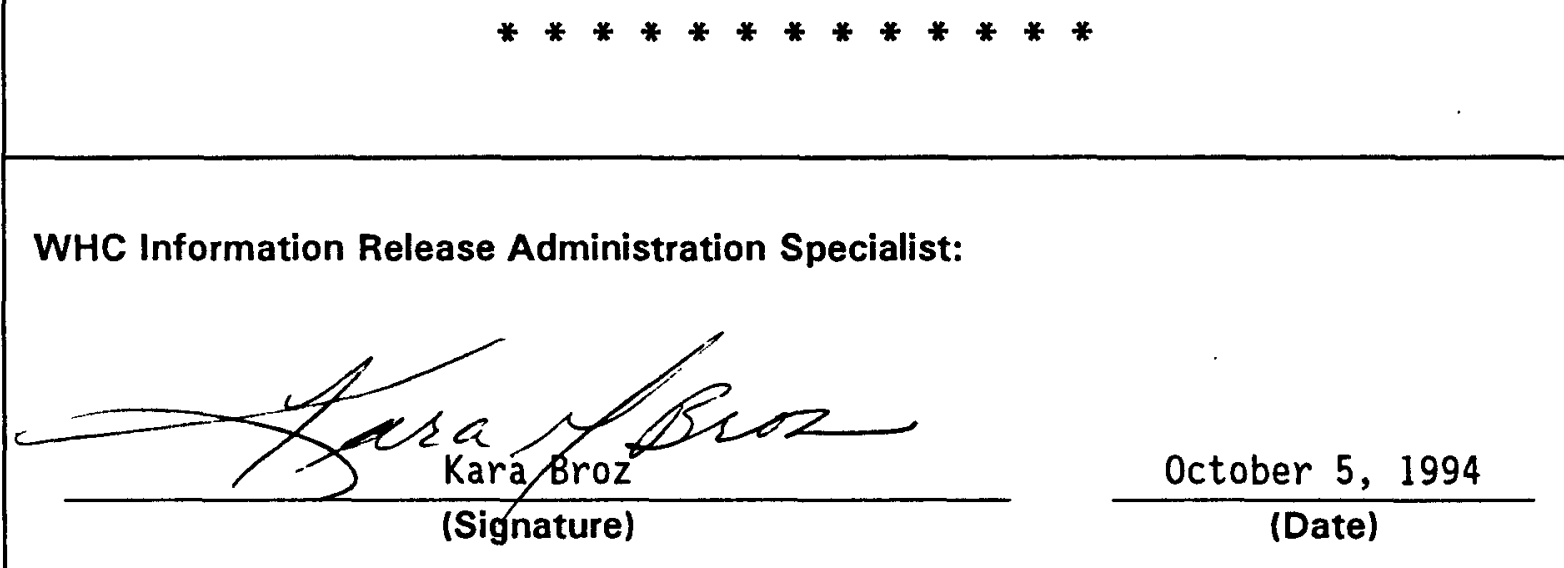




\section{DISCLAIMER}

Portions of this document may be illegible in electronic image products. Images are produced from the best available original document. 
2. Title

TEST PLAN FOR CORE SAMPLING DRILL BIT TEMPERATURE MONITOR

\section{Key Words}

DRILL, BIT, TEMPERATURE, CORE SAMPLING, TESTING
3. Number

WHC-SD-WM-TP- 271
4. Rev No.

0
6. Author

Name: PETER M. FRANCIS

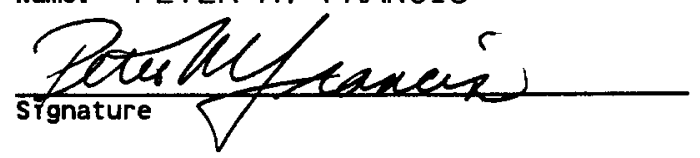

organization/Charge code

7EA40/E23707

\section{APPROVED FOR PUBLIC RELEASE}

$\operatorname{tin} B$

7. Abstract

This document describes the recommended plan for testing the prototype of a dri11 bit temperature monitor developed for core sampling by Sandia National Labs. The device will be tested at their facilities. This test plan documents the tests that Westinghouse Hanford Company considers necessary for effective testing of the system.

8. Purrose AND USE OF DOCUMENT - This document was prepared for use wi thin the U.S. Department of Energy and $i$ ts contractors $T_{t}$ is to be used onk to perform, direct, or integrate work under U.S. Department of Energy contracts. This document is not approved for public release untiv reviewed.

PATENT STATUS - This document sonce it is transmitted in advance of patent clearance is made arable in confidence solely for use in performaper of work unate contracts with the U.S. Department of Energy. This document is not ta be published nor its contents otherwise disseminated or used for purposec other than specified above before patent approval for such release or uge has beep otcured, upon request, from the Patent Counsel, U.S. Department of Energy Field Office, Richland, HA.

DISCLAIMER - This report was prepared as an account of work sponsored by an agency of the United States Government. Neither the United States Government nor any agency thereof, nor any of their employees, nor any of their contractors, subcontractors or their employees, makes any warranty, express or implied, or assumes any legal liability or responsibility for the accuracy, completeness, or any third party's use or the results of such use of any information, apparatus, product, or process disclosed, or represents that its use would not infringe privately owned rights. Reference herein to any specific commercial product, process, or service by trade name, trademark, manufacturer, or otherwise, does not necessarily constitute or imply its endorsement, recommendation, or favoring by the United States Government or any agency thereof or its contractors or subcontractors. The views and opinions of authors expressed herein do not necessarily state or reflect those of the United States Government or any agency thereof.

9. Approval Designator $Q$
10.

RELEASE STAMP

OFTOIAL RELEASE BY WHC

DATE

OCT 051994 
WHC-SD-WM-TP-271 REV. 0

\title{
TEST PLAN FOR CORE SAMPLING DRILL BIT TEMPERATURE MONITOR
}

\author{
PREPARED BY \\ PETER M. FRANCIS \\ Characterization Equipment \\ Tank Waste Remediation System
}

Westinghouse Hanford Company, Richland, Washington

October 1994 


\section{CONTENTS}

1.0 INTRODUCTION . . . . . . . . . . . . . . . . . . . . . . . 1

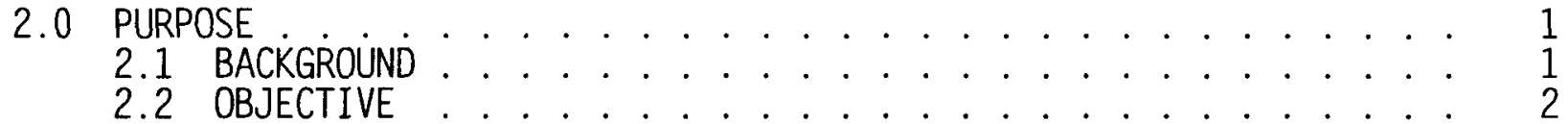

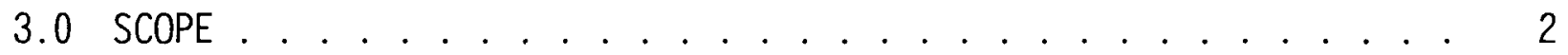

4.0 DESCRIPTION OF TEST . . . . . . . . . . . . . . . . . . 3

4.1 TEST ITEMS $\ldots \ldots$

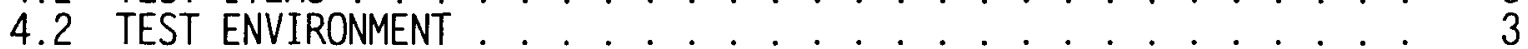

4.3 TEST EQUTPMENT . . . . . . . . . . . . . . . . 3

4.4 DATA . . . . . . . . . . . . . . . . 4

4.5 CRITERIA AND CONSTRAINTŚ

5.0 EXPECTED RESULTS . . . . . . . . . . . . . . . . . . 5

6.0 TEST PROCEDURE . . . . . . . . . . . . . . . . . . . . 5

6.1 ELECTRICAL TESTING . . . . . . . . . . . . . . . . . . . 5

6.2 MECHANICAL TESTING . . . . . . . . . . . . . . . . . . . 6

6.3 ENVIRONMENTAL TESTING

7.0 SAFETY .......................... 7

8.0 QUALITY ASSURANCE . . . . . . . . . . . . . . . . . 7

9.0 ORGANIZATION AND FUNCTIONAL RESPONSIBILITIES . . . . . . . . . . 7

10.0 SCHEDULE . . . . . . . . . . . . . . 8

11.0 REPORTS .................... . . . 8

12.0 REFERENCES . . . . . . . . . . . . . . . . . . . . 9 
WHC-SD-WM-TP-271 REV. 0

\subsection{INTRODUCTION}

A device is being developed to monitor the dri11 bit temperature of the core sampling trucks at the Hanford Site. The device will directly monitor the dri11 bit temperature in real-time to improve the safety and performance of the core sampling process. Sandia National Laboratories (SNL) has devised a bit temperature monitoring (BTM) system that uses an infrared signal to transmit temperature readings from the bit up the drill string. The prototype system must be tested before going into the field, and this document describes the recommended plan for testing this device.

The first phase of testing will take place at SNL to test the function of the system. This will prove the performance capabilities of the BTM device and assist in refining it before final qualification testing at westinghouse Hanford Company (WHC). Certain components will be tested individually, for qualities such as resiliency to the environment. There will also be testing of the entire device for operational and functional performance. Final qualification testing on the core sample truck will take place at a later time and will not be covered in this document.

Successful testing and implementation of the BTM device will improve the operation of the core sample trucks. If the bit temperature can be reliably indicated with this system, it could be used as the sole safety alarm during rotary-mode drilling. In addition, it might allow for a reduction of the nitrogen purge gas to improve sample recovery. The monitor will also be compatible for use in the push-mode core sample truck, for slow rotational drilling without purge gas to improve sample recovery.

\subsection{PURPOSE}

\subsection{BACKGROUND}

At WHC, one of the functions of the Tank Waste Remediation System division is sampling waste tanks to characterize their contents. The pushmode core sampling truck is currently used to take samples of liquid and sludge. Sampling of tanks containing hard salt cake is to be performed with the rotary-mode core sampling system. consisting of the core sample truck. mobile exhauster unit, and ancillary subsystems.

When drilling through the salt cake material, friction and heat can be generated in the dri11 bit. Based upon tank safety reviews, it has been determined that the dri11 bit temperature must not exceed $180^{\circ} \mathrm{C}$, due to the potential reactivity of tank contents at this temperature. Consequently, a dril1 bit temperature 1 imit of $150^{\circ} \mathrm{C}$ was established for operation of the core sample truck to have an adequate margin of safety (Kel1y, 1991).

Unpredictable factors, such as localized heating, cause this buffer to be so great. The most desirable safeguard against exceeding this threshold is BTM. Yet, without any real-time temperature monitoring system readily available, an envelope of operational settings (down force, rotational speed, and purge gas flow) was established through testing, which guarantees that the bit will stay below $150^{\circ} \mathrm{C}$ (Keller, 1993). 
The objective of the BTM system is to provide an indicator to the core sampling operators to warn them that they are approaching the $150^{\circ} \mathrm{C}$ limit. The temperature readout gives another indication of safe drill bit temperature while drilling. The monitoring device may allow the operators to vary operating parameters to improve sample recovery.

In previous research and design efforts, various concepts for a BTM device were evaluated (Francis, 1992) (Johns, 1992). At that time, it was recommended not to proceed with any of the designs because of cost and schedule concerns. The effort to develop a BTM device was recently restarted, and the SNL concept was pursued because it had the most potential for success. Fabrication of a prototype is currently underway. When it is complete, the system wil1 need to be tested for performance capabilities and for compatibility with the core sample truck. This document describes the suggested plan for that testing.

\subsection{OBJECTIVE}

The objective of this testing is to establish the operability and reliability of the temperature monitor device developed by SNL. The testing of the instrument will show that it is compatible with the configuration of the core sampling trucks and show that it can deliver the proper signal and information in the anticipated environment. The tests will include: resilience to the drilling conditions, performance of the system in water, performance with a bowed drill pipe, and functional compatibility with the core sample trucks. The testing will reveal any design problems with the BTM device, which will be alleviated before final qualification testing.

\subsection{SCOPE}

This report out ines the basic plan for the first phase of testing for the prototype BTM device. The second phase is for the final system to be integrated and tested on a core sample truck, which wi 11 take place later and is beyond the scope of this document. In this phase, the prototype device is to be tested for component operation, to show where modification may be needed. The tests are to take place at SNL. Detailed test procedures will not be included in this document, because they depend on the facilities that SNL chooses. The test procedures will be developed by SNL personnel and reviewed by WHC. This test plan suggests what types of tests to run, but detailed descriptions of specific equipment are not included.

The rotary-mode truck is the primary platform for which the BTM device was designed, and most of this test plan is based on the configuration of that truck (e.g., purge gas, universal sampler, and drill bit). Functionality on the push-mode truck is also desired, and testing for conditions specific to it will be included (e.g., water for hydrostatic head). 


\subsection{DESCRIPTION OF TEST}

The BTM device will be tested for electrical, mechanical, and environmental performance. These are the three crucial areas of operation. First, the ability. of the sensors to reliably and repeatedly detect a known temperature is to be established. The second set of tests is to verify the function and performance of the instrument when integrated with a test model of the core sample truck. The environmental tests will qualify the resiliency of particular components in a laboratory setting. These environmental tests are to be run at various points along the development stage by SNL, whenever most appropriate. See section 6.0 for descriptions of the recommended tests.

\subsection{TEST ITEMS}

The BTM device is made up of two major components, the transmitter and the receiver. The transmitter is located inside the drill string, above the grapple weight assembly and is thus called the Above Grapple Assembly (AGA). Negative temperature coefficient thermistors are embedded in the drill bit. from which a wire goes up the core barrel to coils near the AGA. The transformer in the AGA uses an impedance controlled oscillator, which reflects the impedance seen at the coils. This impedance changes with temperature, due to the thermistors in the drill bit. The signal is then converted to infrared and transmitted up the dri1l string by light emitting diodes (LED).

The receiver unit is located just below the bellows assembly inside the quil1 rod. It picks up the infrared signal sent by the AGA and transfers it to a readout on the control panel of the core sample truck. The readout indicates temperature changes in $10^{\circ} \mathrm{C}$ increments until it reaches $140^{\circ} \mathrm{C}$, after which it uses $2^{\circ} \mathrm{C}$ increments. The truck instrumentation will indicate an unsafe drilling condition when the dri11 bit reaches or exceeds $150^{\circ} \mathrm{C}$. For the prototypes, the AGA, communications receiver, and necessary cabling wi 11 be designed and fabricated at SNL.

\subsection{TEST ENVIRONMENT}

Testing will be conducted at a number of SNL facilities. The environmental tests will be performed at labs specific to the particular condition being tested. The operational tests will require a facility where at least $25 \mathrm{ft}$ of dril1 string can be lowered down from a rotating mechanism. There are several test areas at SNL with this capability.

\subsection{TEST EQUIPMENT}

Since the testing will be performed by SNL, they will determine the specific test equipment. This document provides the general outline of testing to be performed and lists some of the key test equipment. The first 
set of tests, for the performance and accuracy of the device, wi11 require a simple model of the drill string arrangement. The following equipment is needed.

- $25 \mathrm{ft}$ of drill string

- Core barrel, fluted, machined with the detents necessary to hold the BTM device and universal sampler

- Motor with chuck to hold and rotate the drill string

- Universal sampler

- Grapple assembly for core sample truck

- Thermocouple attached near thermistors in dri11 bit

- Pressurized air or nitrogen supply.

The second test for proper fit and function requires additional equipment to duplicate the core sample truck configuration. The following parts are required in addition to the above items.

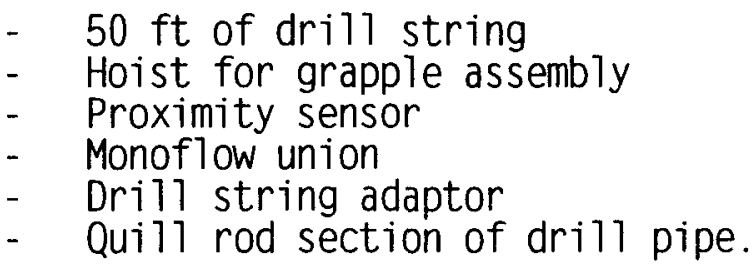

The environmental condition testing will be performed with the equipment available at SNL test labs.

\subsection{DATA}

Data from the tests will be collected with the equipment available at the SNL facilities. Readouts of the temperature are required for the functional tests, in addition to the alarm readouts and time records for the performance of the device. A log book will also be kept to record comments and observations during the tests. The environmental test data wi11 be gathered using the instruments available at each particular lab.

\subsection{CRITERIA AND CONSTRAINTS}

The tests shall prove that the BTM device conforms to the specifications of its criteria document (Francis, 1994). The procedures generated by SNL shall adequately prove the system, and will be reviewed by WHC. The core sample trucks are Safety Class 2 systems, for items controlling the safe operation within the waste tank. Thus, the temperature monitor must conform to al1 Safety Class 2 criteria, including signal redundancy. Testing of the device must establish that the independent temperature signals function properly and that the electronics are intrinsically safe for use inside of explosive gas-generating tanks. The BTM device is designed around safe operation with the core sampling truck, and it will thus be safe to operate with any simulation of the truck for testing. In addition, normal governing restrictions for safety and environmental compliance, already established at SNL, wi11 be adhered to during testing. 


\subsection{EXPECTED RESULTS}

The expectation for this testing is for the performance of the BTM device to fall within the design criteria (Francis, 1994). The testing wi11 show that the BTM system will perform successfully and deliver a reliable temperature indication in the expected environment of the core sample truck and tanks. The ranges and values for the expected test results will be listed in the test procedure, prepared by SNL. The purpose of this testing is not to calibrate the instrument, but to verify its proficiency. Some of the tests will require the components to fall within a set limit of values. Other parts of the test will require only a statement of the maximum capability or tolerance of the particular component. If a part does not meet expectations, it will be modified at SNL and retested until it comes into tolerance.

\subsection{TEST PROCEDURE}

As stated previous $7 y$, the specific test procedures are to be developed by SNL personnel, who will perform the tests. Review and comments will be provided by WHC. The information in this section provides an outline for each of the three prototype experiments that are recommended by WHC at this time.

\subsection{ELECTRICAL TESTING}

In this set of tests, the ability of the BTM device to deliver a reliable signal will be determined. It is suggested to install the BTM system in a drill string, at least $25 \mathrm{ft}$ long. As a control, affix one or more thermocouples near the thermistors in the bit. Take temperature readings from the BTM device and the thermocouple. Apply a heat source to the bit, and compare the temperature variations. This needs to be done several times to determine repeatability of the sensor device. Note that this test is not for calibration of the device, but to verify that a consistent, accurate signal is displayed at the correct temperatures.

The signal will also be tested with water interference. Although the nitrogen purge gas is not expected to affect the performance of the BTM system, the hydrostatic head fluid on the push-mode truck could interfere with the signal. In fact it is anticipated that there is a limit to the range of the system through water with a lithium bromide tracer. The water may also be cloudy from tank waste in the hydrostatic head. It has been suggested that the BTM device could perform through approximately $10 \mathrm{ft}$ of the fluid, but no fixed result is expected. The test will provide maximum capability in this scenario, and the operation of the push-mode truck can be altered accordingly. The same setup and test procedure as the first signal test will be used, except with the drill string filled with the appropriate fluid. 


\subsection{MECHANICAL TESTING}

To determine the proper mechanical performance of the BTM device, it must be tested in an operating scenario. A simulation of the core sample truck will be devised, so the BTM system can tested while drilling into a simulant (to be prepared at SNL). This series of tests will confirm the proper design configuration of the BTM device and its compatibility with the truck. These tests will also determine the effects of drilling, such as hindering the signal, dislodging the latch mechanism, signal interference from airborne particulate, or harming the electronics (long-term effects of vibration will be explored in section 6.3 ).

The device will be installed onto truck simulation and put through the normal operating procedures for core sampling. The AGA module will be lowered down with a sampler and latched in. Drilling will begin with the purge gas flowing, and temperature readings will be taken. After the sample is complete, the pintle rod will be pulled up with the grapple, and the AGA will be pulled up along with it. The proximity sensor will detect when the AGA has reached the top. The grapple cable will slow to a stop and the pintle rod will be dropped, as in the core sampling procedure. This procedure should be repeated successfully at least three times.

During the operation, a bow can develop in the drill string, which might interfere with the infrared signal. This can be tested in a vertical or horizontal position. If there is a facility available at SNL to allow $50 \mathrm{ft}$ of drill pipe to be rotated as well as bowed up to $2 \mathrm{ft}$ in radius, a signal test could be run in the vertical position. The other option is to lay the drill string horizontal, suspended at both ends, and manually create a camber in the middle while it is rotating. It is important to have the drill string rotating, as this may have an effect on the signal.

\subsection{ENVIRONMENTAL TESTING}

The BTM system will encounter a harsh environment during operation. These tests will verify the functionality of the components in extreme environments, including mechanical shock, compressive forces, vibration, temperature variations, high pressure, ionizing radiation, water submersion, water washes, and corrosive chemicals. The limits of these tests will be based on the criteria list for the system (Francis, 1994). The AGA will have to undergo all of these tests. The receiver needs to be tested only for temperature, pressure, and radiation limits. 


\subsection{SAFETY}

The level of safety reviews and assurances is under the discretion of the departments performing the tests at SNL. However, there are some safety issues particular to this testing worth noting. When rotating a considerable length of drill string, there is the hazard of the pipe swinging and colliding with objects. Appropriate restraining measures will need to be incorporated. Hazards may exist with the environmental testing, but not beyond the limitations and controls of the facility.

\subsection{QUALITY ASSURANCE}

The SNL quality assurance division will review their test procedures and witness the testing, as appropriate. The standards and calibrations already in place at the SNL facilities are satisfactory for the requirements of this testing. Qualification of the BTM device is the responsibility of the SNL development team, and thus for this phase of testing the level of quality assurance is under the discretion of the SNL team. The device will also be reviewed and inspected by WHC Quality Assurance when ownership is transferred to WHC. There may also be participation by WHC Quality Assurance during the execution of the tests.

\subsection{ORGANIZATION AND FUNCTIONAL RESPONSIBILITIES}

The primary operating department for testing of the BTM system prototype is SNL Instrumentation Development. They wi 11 be supported throughout by the WHC engineering team, the customer for this device. The responsibilities of SNL include: conducting the tests: gathering the data; reporting on the data. By performing the tests at the facilities at SNL, rather than WHC, any component modifications can be made there quickly. As stated before, the use of safety or environmental assurance will be under the discretion of the SNL engineering and testing teams.

The responsibilities of the Characterization Equipment organization at WHC will be: preparation and release of this Test Plan document; engineering support and guidance for the tests. If necessary, information or purchase of equipment needed for the testing will be provided to SNL from the Characterization Equipment group.

The Analytical Hardware Development organization of WHC will be responsible for program management and project funding that supports this testing effort.

The WHC Quality Assurance organization will aid in the review of test documentation, including the SNL test procedure. Members of this group could also attend the testing, as appropriate. 


\subsection{SCHEDULE}

Preparations for testing will begin upon completion of the prototype BTM device. It is anticipated that this will be at the beginning of fiscal year 1995. A rough schedule of the testing would be the following.

PREPARE PROCEDURES (SNL)

PERFORM ENVIRONMENTAL TESTS

FAB/PURCHASE TEST EQUIPMENT

PERFORM ELECTRICAL TESTS

PERFORM MECHANICAL TESTS

COMPILE AND INTERPRET RESULTS

PREPARE AND ISSUE TEST REPORT
OCT 10 - OCT 28

OCT 10 - DEC 7 (INTERMITTENT)

OCT 17 - NOV 4

NOV 7 - NOV 18

NOV $21-D E C 7$

DEC 8 - DEC 12

DEC 12 - DEC 22

\subsection{REPORTS}

The required document for this testing effort is the test report to be prepared at the conclusion of testing. Informal reporting will take place throughout the testing process, but the test report is the only required document. It will be issued from SNL to WHC as an official test report. The anticipated content and format of the report shall be specified in the SNL test procedure. 


\subsection{REFERENCES}

Francis, P. M., 1992. Thermistor Concepts For Bit Temperature Monitoring, WHC-SD-WM-ER-165, Rev. 0, Westinghouse Hanford Company, Richland, Washington.

Francis, P. M., 1994, Criteria for Core Sampling Bit Temperature Monitor, WHC-SD-WM-CR-057, Rev. 0, Westinghouse Hanford Company, Richland, Washington.

Johns, B. R., 1992, Rotary Mode Core Sampling Temperature Monitoring. WHC-SD-WM-RPT-038, Rev. 0, Westinghouse Hanford Company, Richland, Washington.

Keller, C. M., 1993, Core Drill Operating Envelope Test Report, WHC-SD-WM-TRP-123, Rev. 1, Westinghouse Hanford Company, Richland, Washington.

Kel1y, S. E., 1991. Development Criteria for the Rotary Mode, Universa 7 Sampler \& Bit, and NPH Elimination Systems, WHC-SD-WM-CR-044, Rev. 0 , Westinghouse Hanford Company, Richland, Washington. 